\title{
The Influence of School Climate on Strengthening Student Character Education in SMP Baturaja Timur District
}

\author{
Eva Darnela $\left.{ }^{1 *}\right)$ Bukman Lian ${ }^{2}$, Rohana $^{2}$ \\ ${ }^{1}$ SMP Negeri 1 OKU \\ ${ }^{2}$ Universitas PGRI Palembang \\ "Corresponding author. Email: evadarnela@gmail.com
}

\begin{abstract}
This reseach aimed to determine, describe, and analyze the effect of school climate on strengthening character education of the students at Junior High Schools in East Baturaja District. The approach of the research was quantitative research. The population of this study was teachers of State Junior High Schools in East Baturaja District. The samples were taken through a purposive sampling technique as many as 152 people. The data collecting in this research using the questioner. Data were analyzed using the SPSS v.21 program. The results of this study suggest that there is a climate influence on character education. The results of this study showed that there was an effect of school climate on character education. This research is hoped to be useful for making school policy in improving the school climate and students' character education.
\end{abstract}

Keywords: School Climate, Character Education, Student.

\section{INTRODUCTION}

In accordance with [1] concerning the National Education System in Article 3, education functions to develop an ability and help shape the dignified character and civilization of the nation aimed at educating the nation's life. So that national education aims to develop the existing potential of students so that they can become human beings who believe and fear God Almighty, have noble, healthy, knowledgeable, agile and capable, creative and innovative, independent, and democratic citizens. and take responsibility.

The implementation of the National Education System Law mentioned above is the [2] concerning Strengthening Character Education which concludes that the term Strengthening Character Education is an educational movement that is under the responsibility of the education unit which aims to strengthen the character of students through harmonization results. sports, feelings, thoughts, and sports by involving and requiring cooperation between educational units, families, and communities that are part of the National Movement for the Mental Revolution.

Based on the results of observations made by researchers on students at State Junior High Schools, in general, it shows that there is a decrease in the morale/character of students. The success of school education is measured based on the achievement of the final results through semester examinations. A high score is the best achievement of students in the National Examination. As a result, students today tend to lose their identity as an educated figure. They tend to lose noble values and personalities that are in harmony with the nation's culture. Immoral behavior and attitudes are often shown by smoking behavior in the school environment, brawls, bullying, cyberstalking, cyberbullying, bullying, going home without the teacher's permission, jumping the fence, cheating tests, acts of disrespect and indifference to the teacher, and disrespectful morals. others include mental disorders due to online game addiction.

The increasing number of cases that occurred in the SMP Negeri 1 OKU environment, in the 2017/2018 school year there were 48 violations in the even semester, 91 cases occurred in the odd semester, and 58 cases in the even semester of the 2018/2019 academic year. Meanwhile, in the $2019 / 2020$ school year there were 42 violations in the odd semester and 36 violations in the even semester. These types of violations vary, from fighting, arriving late, bullying, and so on. The figures obtained from guidance and counseling sources 
do not include data on violations handled by subject teachers and picket teachers.

In addition to the data above, based on the results of interviews with counseling officers, several cases occurred in state SMP 13 OKU, such as cases of calling parents for truancy, smoking, fighting, there were 54 cases, 17 cases of suspension were due to repeated smoking, promiscuity. and pornography, and there were 9 cases of resignation and/or moving due to cases of promiscuity, smoking, naughty, marriage, including being economically disadvantaged. Figures are obtained from sources of school guidance and counseling.

The school environment is not yet conducive to fostering the character of students, it can be seen that the number of mentors in activities is very close to the character-building of students. One example of the number of students at State Junior High Schools in East Baturaja District, amounting to 4,754 people, is not proportional to the number of counseling guidance teachers, that is 15 teachers, 10 religious or spiritual activity supervisors, and only 1 Character Education coach person. So on average, one school has 3 counseling guidance teachers, 2 spiritual or religious guidance teachers, while only $0.7 \mathrm{KDP}$ teachers are specialized.

There are several indicators of the success of character education in schools, [3] stated that there are 21 graduation standards, such as 1) Practicing religious teachings according to the stage of children's development. 2) Understanding the strengths and weaknesses. 3) Showing a confident attitude. 4) Understanding the social rules that apply in a wider environment. 5) Respecting the diversity of religions, cultures, ethnicities, races, and socio-economic groups in the national scope. 6) Finding and applying information from the surrounding environment and other sources logically, critically, and creatively. 7) Demonstrating the ability to think logically, critically, creatively, and innovatively. 8) Demonstrating the ability to learn independently according to its potential. 9) Showing the ability to analyze and solve problems in everyday life. 10) Describing natural and social phenomena. 11) responsibly utilizing the environment. 12) Applying the values of togetherness in the life of the community, nation, and state for the sake of realizing unity in the unitary state of the Republic of Indonesia. 13) Appreciating national arts and culture. 14) Appreciating work assignments and can work. 15) Applying a clean, healthy, fit, safe life and make good use of free time. 16) Communicating and interacting effectively and politely. 17) Understanding the rights and obligations of oneself and others in socializing in society and respecting differences of opinion. 18) Showing a penchant for reading and writing simple short manuscripts. 19) Demonstrating skills in listening, speaking, reading, and writing in Indonesian and simple
English. 20) Mastering the knowledge required to attend secondary education. 21) Having an entrepreneurial spirit.

According to [4] indicators of the success of character education programs show the 5 main values of national character, that is religious, nationalist, independent, mutual cooperation, and integrity. So that the indicators of strengthening the character of students in this study are sourced from the values of national character, that is religious, nationalist, independent, mutual cooperation, and integrity.

School climate is a condition of the school environment physically and socially as an organization. This is in accordance with the opinion of [5] "Organizational climate, also called organizational atmosphere, is a series of work environment characteristics that can be measured based on the collective perceptions of people who live and work in that environment and are shown to influence their motivation and behavior."

A school is an organization that will be influenced by the environment or its member components within the school community. [6] stated that organizational climate is a set of measurable properties of the work environment that is felt/seen directly or indirectly by people who live and work in that environment so that it is assumed to affect motivation and their behavior. Organizational climate provides a dynamic of life within the organization and greatly influences its human resources.

Meanwhile, [7] defined school climate as "the atmosphere or conditions that arise as a result of the relationship between the principal and the teacher, the teacher and the teacher, the teacher and the students or the relationship between students which characterizes the school which influences the teaching and learning process in school". Furthermore, [8] said that the relationship between teachers and students will affect the success of developing student pro-social behavior, the formation of student character is influenced by the example of teachers in speaking polite words, disciplined religion, democratic, nationalist, grateful and caring for the environment.

Milton in [9] defined organizational climate as the quality of the internal environment which is relatively long-lasting, becomes an experience for each member of the organization, influences their behavior, can be discussed in a set of characteristics or attributes (traits) and differentiates between one organization with other organizations.

According to [6] "organizational climate includes aspects such as structural, responsibility and reward". [10] "school climate is a relatively constant quality of the school environment experienced by participants, influencing their behavior, and based on their collective perceptions of behavior in school". Thus it can be said 
that the school climate is the atmosphere that school residents feel that can affect their behavior.

According to [11] "School climate is related to the feelings of school members in their interactions with the social and material/physical environment. The social environment in which there is a relationship between teachers and students, communication between principals and teachers, relationships between teachers and staff, and so on".

[11] further explained that the school climate is an environmental situation that is felt by every school member. The school climate contains how each school member perceives the school environment. A good school climate will provide comfort for students so that school goals will be able to be achieved. School climate is a system that consciously harmonizes the activities carried out by its members and influences their behavior. School as an organization that has objective goals to be achieved and to achieve these objective goals a good school climate is needed. This good school climate refers to the working conditions between school leaders and teachers in achieving these objective goals. If work conditions are developed properly and transparently, it will result in a better school climate and teaching and learning process in schools so that it will have a positive impact on students who affect them.

Furthermore, according to Siagian in [12] that the success of an organization is determined by many factors and one of them is the organizational climate which means as a physical and non-physical working condition and a work environment that also affects behavior and motivational factors which needs the attention of every leader in the organization.

Based on some of the opinions above, the researcher can conclude that the school climate is a condition or situation of the school environment that arises as a result of the interaction between school members, whether pleasant or unpleasant, which includes physical or social school members, which can affect the achievement of school goals.

The urgency of a conducive school climate is needed in building the character of students in schools. Marshall in [13] said that the importance of school climate for various parties, namely: 1) school climate can affect many people in schools, 2) school climate in high-risk cities shows that a positive environment supports and a school climate-conscious culture is significant in shaping the success of urban students in obtaining academic degrees, 3) positive interpersonal relationships and optimal learning opportunities for students in all demographic environments can increase achievement and reduce maladaptive behavior, 4) a positive school climate is related to increased job satisfaction for school personnel, 5) the school climate can play an important role in providing a healthy and positive school atmosphere, 6) the interaction of various schools and classroom climate factors can provide support that allows all members of the school community to learn and teach optimally, 7) the school climate includes trust, respect, mutual understand the obligations and concerns for other welfare, have a strong influence on educators and students, the relationship between students and academic achievement and overall school progress.

A positive school climate is a rich environment for personal growth and academic success. This is according to the opinion of [14], that the school climate plays an important role in supporting the implementation of a safe, peaceful, and conducive learning process in order to easily achieve educational goals. Progress or withdrawal of the school depends on the ability of the school to create its environment and the willingness of the environment to accept its existence.

Dimensions of school climate According to Moos and [15] "suggested that school climate can be measured by four indicators, namely indicators of interpersonal relationships, indicators of personal growth or development, indicators of system change and improvement, and indicators of the physical environment". Furthermore, according to Moos and Arter in Hadiyanto (2016: 90) that the dimensions of the school climate consist of: "1), dimensions of relationships, 2) dimensions of personal growth/development, 3) dimensions of change and system improvement and 4) dimensions of the physical environment".

Each dimension of the school climate has a scale. First, having a relationship dimension includes the scale of affiliation, rift, intimacy, closeness, and involvement. Second, the dimensions of personal growth and development include the scale of professional interest, barriers, beliefs, performance standards, and task orientation. Third, the dimensions of system change and improvement include the scale of staff freedom, participation in decision making, innovation, work pressure, clarity, and supervision. The four physical dimensions include the scale of resource capability and environmental comfort.

Based on some of the opinions above, the indicators for measuring the school climate in this study are seen from the first, having a relationship dimension including the scale of affiliation, rift, intimacy, closeness, and involvement, such as the quality of interactions or relationships between students, educators, and staff, the fairness of treatment learners by teachers and staff, the level of competition and social comparison among students, and the level of contribution of students, teachers, and staff in decision making in schools.

Second, the dimensions of personal growth and development include the scale of professional interest, 
barriers, beliefs, performance standards, and task orientation. Third, dimensions of system change and improvement include the scale of staff freedom, participation in decision making, innovation, work pressure, clarity, and supervision such as quality of instructions, teacher expectations on student achievement, monitoring of student progress, and reporting of learning outcomes to students and parents. Fourth, the physical dimension includes the scale of resource capability and environmental comforts such as the appearance of the building and the atmosphere of the classroom, the size of the school and the ratio of students and teachers in the classroom, availability of resources, and safety and comfort.

[16] found that school climate can affect responsibility attitudes with $\mathrm{t}$ count for the school climate of $2.725>t$ table of 2.0181 or sig $0.009<0.05$. It means that the influence of the school climate on the attitude of responsibility is very significant. With an $\mathrm{R}$ Square of 0.15 or $15 \%$, it means that the attitude of responsibility is influenced by the school climate. [11] stated that the school climate can support realizing education as expected. A harmonious and conducive school climate can be seen through the social and physical environment in schools. The success of character education in schools is determined by the environment and existing school climate compared to the presentation of subjects.

\section{METHODS}

\subsection{Types of research}

This research used a quantitative approach to find the influence of school climate on strengthening the character education of Junior High School students in East Baturaja District in 2020/2021. In this study, there is one independent variable and one dependent variable. School climate as the independent variable (independent school climate as $\mathrm{X}$ ), while the character education of students as the dependent variable is stated as Y.

Data collection techniques in this study were questionnaire and documentation. The documentation in this study was only used as a complement to strengthen and find out existing data information. The questionnaire in this study used a closed questionnaire in which the answer to the questionnaire or statement was available so that the respondent only needed to choose the answer that was already available according to the real conditions and this was aimed at the teacher to find out the school climate and character education of students. This is in accordance with the opinion of [17] that "research instruments are used to measure the value of the variables under study". Furthermore, respondents were provided with five alternative answers which are Likert scale interval data in accordance with [17], that the Likert scale is used to measure attitudes, opinions, and perceptions of a person or group of people about social phenomena. Alternative answers consist of: always, often, ever, sometimes, and never, with a score of $5,4,3,2$, and 1 .

\subsection{Subject and data collection}

The subjects in this study were teachers of State Junior High Schools in East Baturaja District. Sampling was carried out by using purposive sampling technique as many as 152 teachers consisting of 2 schools, that is SMPN 1 OKU and SMPN 13 OKU. The research data were obtained by using a questionnaire to determine the effect of school climate on strengthening the character education of students. The instrument used has been through validation and reliability. Validation is obtained from experts and the results of field trials.

The data analysis process in this study included tabulating the data for each variable, then calculating the data assumption test, and then testing the hypothesis. Data processing is assisted by the SPSS V 21 program.

\section{RESULTS AND DISCUSSION}

Based on the results of data processing collected from 152 teachers of State Junior High Schools in East Baturaja District, the descriptive statistics table shows that the mean value is 87.76 . The highest value is 100 and the lowest value is 41 . Meanwhile, the results of testing with the regression model show that the results of testing the hypothesis using the t-test are received significantly. The results show that the t value is 10.420 . Then compare the value of $t$-count (10.420)> $t$ table (1.976). The results of this study indicate that the school climate has a significant effect on strengthening the character education of students. Then the large contribution of school climate to strengthening students' character education was obtained by the value of an effective contribution of 44, which means an increase in the strengthening of character education for students due to the influence of school climate by $44 \%$.

The value obtained in this study proves that the school climate affects strengthening the character education of students. These findings also indicate that a conducive school climate must be the full attention of all school members because it will affect the strengthening of character education for students. If all members of the school do not maintain good relationships, physical facilities are not fulfilled, this will have a negative effect on efforts to strengthen the character education of students.

A conducive school climate is a prerequisite for strengthening the character education of students. A safe, comfortable school climate can develop the character of students in the school environment. The 
school climate can be seen through the social and physical environment at school. The social environment is closely related to harmonious interactions between teachers and school principals and teachers and teachers and so on. While the physical environment can be seen based on the completeness, arrangement, maintenance of learning sfacilities so that it is very supportive in carrying out learning. The existence of a harmonious and conducive environment is the basis for implementing character education in schools. Students as character education learners obtained through the formal curriculum will not be fully successful without being supported by a supportive school climate. The success of character education in schools is determined by the environment and existing school climate compared to the presentation of subjects.

\section{CONCLUSION}

Based on data analysis and hypothesis testing, it can be concluded that there is a significant effect of school climate on strengthening the character education of students at State Junior High Schools in East Baturaja District.

\section{REFERENCES}

[1] Undang-Undang nomor 20 tahun 2003 tentang Sistem Pendidikan Nasional

[2] Peraturan Presiden No. 87 Tahun 2017 tentang Penguatan Pendidikan Karakter

[3] Mulyasa. (2018). Manajemen Pendidikan Karakter. Jakarta:Bumi Aksara.

[4] Hendarman. (2017). Konsep dan Pedoman PPK.Pusat Analisi dan Sinkronisasi Kebjakan Jakarta: Sekretaris Jenderal Kementerian Pendidikan dan Kebudayaan

[5] Priyono. 2010. Manajemen Sumber Daya Manusia. Siduarjo: Zifatama Publisher.

[6] Pratiwi, H. (2016). Pengaruh Kepemimpinan, Iklim Organisasi, dan Budaya Kerja terhadap Motivasi Kerja dalam meningkatkan kinerja pegawai PT. Admiral Lines Belawan. Jurnal Bisnis Administrasi, 5(2) : 42-48.

[7] Hadiyanto. (2016). Teori \& Pengembangan Iklm Kelas \& Iklim Sekolah.

[8] Lian, B., Kristiawan, M., Primasari, D., \& Prasetyo, M. (2020). Teachers' Model In Building Students' Character. Journal of Critical Reviews. 7. 927-932.

[9] Setiawan, KC. 2015. Pengaruh Iklim Organisasi Terhadap Kinerja Karyawan Level Pelaksana di Divisi Operasi PT, PUSRI Palembang. PSIKISJurnal Psikologi Islami.1(1) : 23-32

[10] Saputra, A. (2016). Perilaku Kepala Sekolah dan Iklim Sekolah Terhadap Peningkatan Mutu
Sekolah di SMK. Edusentris, Jurnal Ilmu Pendidikan dan Pengajaran, 3(3) :269-280

[11] Darmono, A. (2016). Membangun Pendidikan Karakter Berbasis Iklim Sekolah. Jurnal Studi Islam dan Sosial, 10(1): 113.https://adoc.pub/membangun-pendidikankarakter-berbasis-iklim-sekolah-al darm.html

[12] Pratami, FA., Harapan, E., Arafat., Y. (2018). Influence Of school Principal And Organizationl Climate Supervision On Teachers' Performance.

[13] Antoni, A. (2017). Pengaruh Iklim Sekolah dan Kinerja Guru Terhadap Motivasi Belajar Siswa SMK Negeri 1 Bukit Kemuning Kecamatan BukitKemuning Kabupaten Lampung Utara. Repository UIN Raden Intan Lampung. http://repository.radenintan.ac.id/1322/

[14] Karyawati, S.,Abdullah, G., dan Murniati, NAN. (2017). Pengaruh Kepemimpinan Kepala Sekolah Dan Iklim Sekolah Terhadap Efektivitas Sekolah Dasar Di Kecamatan Slawi. Jurnal Manajemen Pendidikan. 6(1) : 101-116

[15] Triyanah, E., dan Suryadi, E . (2016). Iklim Sekolah sebagai Determinan Semangat Kerja Guru sekolah Menengah Kejuruan. Jurnal Pendidikan Manajemen Perkantoran 1 (1): $72-79$ http://ejournal.upi.edu/index.php/jpmanper/article/ view/00000

[16] Erfita, F., Suntoro, I., Yanzi, H. (2018). Pengaruh Iklim Sekolah Dan Konsep Diri Terhadap Pembentukan Sikap Tanggung Jawab.Jurnal Kultur Indonesia. (5):1-13. https://media.neliti.com/media/publications/24980 3-pengaruh-iklim-sekolah-dan-konsep-diri-t98da0dfc.pdf

[17] Sugiyono. (2016). Metode Penelitian Pendidikan Pendekatan Kuantitif, Kualitatif, dan $R \& D$. Bandung: Alfabeta Bandung 